\title{
Psychrobacter piscatorii sp. nov., a psychrotolerant bacterium exhibiting high catalase activity isolated from an oxidative environment
}

Correspondence

Isao Yumoto

i.yumoto@aist.go.jp

\author{
Isao Yumoto, ${ }^{1,2}$ Kikue Hirota, ${ }^{1}$ Hideyuki Kimoto, ${ }^{1,3}$ Yoshinobu Nodasaka, ${ }^{4}$ \\ Hidetoshi Matsuyama ${ }^{3}$ and Kazuaki Yoshimune ${ }^{1}$
}

\footnotetext{
${ }^{1}$ Research Institute of Genome-based Biofactory, National Institute of Advanced Industrial Science and Technology (AIST), Tsukisamu-Higashi, Toyohira-ku, Sapporo 062-8517, Japan

${ }^{2}$ Graduate School of Agriculture, Hokkaido University, Kita-ku, Sapporo 060-8589, Japan

${ }^{3}$ Department of Bioscience and Technology, School of Engineering, Tokai University, Minamisawa, Minami-ku, Sapporo 005-8601, Japan

${ }^{4}$ Laboratory of Electron Microscopy, Graduate School of Dentistry, Hokkaido University, Kita-ku, Sapporo 060-8586, Japan
}

\begin{abstract}
A Gram-negative, non-motile, psychrotolerant bacterium exhibiting high catalase activity, designated strain $\mathrm{T}-3-2^{\top}$, was isolated from a drain of a fish-processing plant. Its catalase activity was $12000 \mathrm{U}$ (mg protein) ${ }^{-1}$, much higher than the activity of the other Psychrobacter strains tested. The strain grew at $0-30{ }^{\circ} \mathrm{C}$ and in the presence of $0-12 \% \mathrm{NaCl}$. The predominant isoprenoid quinone was ubiquinone-8 $(\mathrm{Q}-8)$, and $\mathrm{C}_{16: 1} \omega 9 c$ and $\mathrm{C}_{18: 1} \omega 9 c$ were the predominant cellular fatty acids. The DNA G $+\mathrm{C}$ content of strain T-3-2 ${ }^{\top}$ was 43.9 mol\%. $16 \mathrm{~S}$ rRNA gene sequence phylogeny suggested that strain $\mathrm{T}-3-2^{\top}$ is a member of the genus Psychrobacter, with the closest relatives being the type strains of Psychrobacter nivimaris (99.2\% similarity), $P$. aquimaris $(98.7 \%)$ and $P$. proteolyticus $(98.5 \%)$. DNA-DNA hybridization showed less than $65 \%$ relatedness with these strains. A phylogenetic tree based on gyrB gene sequences was more reliable, with higher bootstrap values than the 16S rRNA gene sequence-based tree. The result also differentiated the isolate from previously reported Psychrobacter species. Owing to the significant differences in phenotypic and chemotaxonomic characteristics and the phylogenetic and DNA-DNA relatedness data, the isolate merits classification within a novel species, for which the name Psychrobacter piscatorii sp. nov. is proposed. The type strain is T-3-2 ${ }^{\top}\left(=\mathrm{JCM} 15603^{\top}\right.$ $=$ NCIMB $14510^{\top}$ ).
\end{abstract}

Micro-organisms living under extreme conditions such as high and low temperature and $\mathrm{pH}$, high salinity and high hydrothermal pressure are called extremophiles and have acquired the ability to adapt to an extreme environment (Gerday \& Glansdorff, 2007). Although there are several examples of interactions between oxidative stress produced by host micro-organisms and parasitic or symbiotic microorganisms (Katsuwon \& Anderson, 1992; Rocha et al., 1996; Visick \& Ruby, 1998; Jamet et al., 2003; Merle et al., 2007), there have been only a few reports of specific microorganisms that inhabit environments with hyperoxidative stress caused by factors such as high $\mathrm{H}_{2} \mathrm{O}_{2}$ concentrations.

We previously isolated Exiguobacterium oxidotolerans $\mathrm{T}-2-2^{\mathrm{T}}$, exhibiting very strong $\mathrm{H}_{2} \mathrm{O}_{2}$ tolerance, from the upstream part of a $\mathrm{H}_{2} \mathrm{O}_{2}$-containing wastewater in a fish egg-

The GenBank/EMBL/DDBJ accession numbers for the 16S rRNA gene and gyrB sequences of strain T-3-2 ${ }^{\top}$ are AB453700 and AB490498. processing plant in Hokkaido, Japan, in which $\mathrm{H}_{2} \mathrm{O}_{2}$ is used as a bleaching agent (Yumoto et al., 2004). During the search for $\mathrm{H}_{2} \mathrm{O}_{2}$-tolerant micro-organisms and micro-organisms possessing high catalase activity, we have found that the wastewater environment in this fish egg-processing plant is appropriate for the isolation of such micro-organisms. This micro-organism also exhibits high catalase activity. As a consequence, both the micro-organisms and their enzymes might be induced to adapt to the environment.

During screening for micro-organisms with high catalase activity from the $\mathrm{H}_{2} \mathrm{O}_{2}$-containing wastewater, strain T-3$2^{\mathrm{T}}$ was isolated. It is of considerable interest to identify the taxonomic position of such a unique extremophile. The isolate was examined on the basis of its phenotypic and chemotaxonomic characteristics; phylogenetic analysis based on 16S rRNA gene sequences and DNA-DNA hybridization showed that the isolate can be identified as belonging to a novel species of the genus Psychrobacter. 
$\mathrm{H}_{2} \mathrm{O}_{2}$-resistant isolates were selected by plating $0.2 \mathrm{ml}$ wastewater sample onto a $10 \mathrm{mM} \mathrm{H_{2 }} \mathrm{O}_{2}$-supplemented PYS-2 agar plate ( $\mathrm{pH} 7.5)$ containing $8 \mathrm{~g}$ polypeptone (Nihon Pharmaceutical), 3 g yeast extract (Kyokuto) and $5 \mathrm{~g} \mathrm{NaCl}$, followed by incubation at $27{ }^{\circ} \mathrm{C}$ for 1 week. From the incubated plate, one colony was picked and transferred to a PYS-2 agar plate. Single isolated colonies were serially transferred five times on PYS-2 agar. Psychrobacter nivimaris DSM $16093^{\mathrm{T}}, \quad P$. proteolyticus DSM $13887^{\mathrm{T}}$ and $P$. aquimaris DSM $16329^{\mathrm{T}}$ were used as reference strains for DNA-DNA hybridization. The microorganisms were cultivated using PYS-2 medium at $27{ }^{\circ} \mathrm{C}$ until the early stationary phase of growth.

For phenotypic characterization, PYS-2 medium was used as the basal medium. The culture was incubated at $27{ }^{\circ} \mathrm{C}$ for 2 weeks and the experiment was performed three times. Morphological, physiological and biochemical tests were performed as described by Barrow \& Feltham (1993). Carbohydrate metabolism was tested by the method of Hugh \& Leifson (1953), and the result was checked daily until 2 weeks after inoculation. Alginase activity was determined after an inoculated agar plate was overlaid with ethanol after 10 days of cultivation.

For the comparative study of catalase activity, activity was estimated as described previously (Yumoto et al., 2004). The catalase activities of strain $\mathrm{T}-3-2^{\mathrm{T}}, P$. nivimaris DSM $16093^{\mathrm{T}}, P$. proteolyticus DSM $13887^{\mathrm{T}}$ and $P$. aquimaris DSM $16329^{\mathrm{T}}$ were respectively $12000,15,29$ and $1800 \mathrm{U}$ $(\mathrm{mg} \text { protein })^{-1}$.

To observe negatively stained cells by transmission electron microscopy, strain $\mathrm{HT}-3^{\mathrm{T}}$ was grown on a PYS-2 agar slant. The procedures for preparation and observation by transmission electron microscopy were described previously
(Yumoto et al., 2001). The morphological, physiological and biochemical characteristics of the isolate are given in the species description. The isolate was a Gram-negative and non-motile coccobacillus $(0.9-1.1 \times 1.3-1.6 \mu \mathrm{m})$. The genus Psychrobacter is described as comprising psychrophilic to psychrotolerant, halotolerant, aerobic, non-motile, Gramnegative coccobacilli. The characteristics of the isolate were similar to those of the genus Psychrobacter.

Whole-cell fatty acids and isoprenoid quinones were analysed as described previously (Yumoto et al., 2001). The fatty acids of strain HT- $3^{\mathrm{T}}$ comprised $\mathrm{C}_{10: 0}(1.7 \%)$, $\mathrm{C}_{12: 0}(2.6 \%), \mathrm{C}_{16: 0}(2.2 \%), \mathrm{C}_{16: 1} \omega 7 c(1.2 \%), \mathrm{C}_{16: 1} \omega 9 c$ $(20.4 \%), \mathrm{C}_{17: 0}(1.0 \%), \mathrm{C}_{17: 1} \omega 8 c(5.9 \%), \mathrm{C}_{18: 0}(8.9 \%)$, $\mathrm{C}_{18: 1} \omega 9 c(53.7 \%)$ and $\mathrm{C}_{12: 0} 3-\mathrm{OH}(2.8 \%)$. The major isoprenoid quinone was $\mathrm{Q}-8$.

Bacterial DNA was prepared according to the method of Marmur (1961). The DNA base composition was determined by the method of Tamaoka \& Komagata (1984). The DNA G + C content of strain $\mathrm{HT}-3^{\mathrm{T}}$ was $43.9 \mathrm{~mol} \%$, which is similar to those of the type strains of $P$. nivimaris (42 mol\%), P. proteolyticus (43.6 mol\%) and P. aquimaris (43.2 $\mathrm{mol} \%)$.

The 16S rRNA gene was amplified by PCR using primers 9F (5'-GAGTTTGATCCTGGCTCAG-3') and 1541R (5'AAGGAGGTGATCCAGCC-3'). The PCR product was sequenced directly by the dideoxynucleotide chain-termination method using a DNA sequencer (ABI PRISM 3100; Applied Biosystems). A 16S rRNA gene sequence of $1510 \mathrm{bp}$ was obtained from strain $\mathrm{T}-3-2^{\mathrm{T}}$ and analysed. Multiple alignments of the sequences were performed and the nucleotide-substitution rate ( $K_{\text {nuc }}$ value) was calculated. The $16 \mathrm{~S}$ rRNA gene sequence similarity of T-3-2 ${ }^{\mathrm{T}}$ with previously reported strains was determined, and a

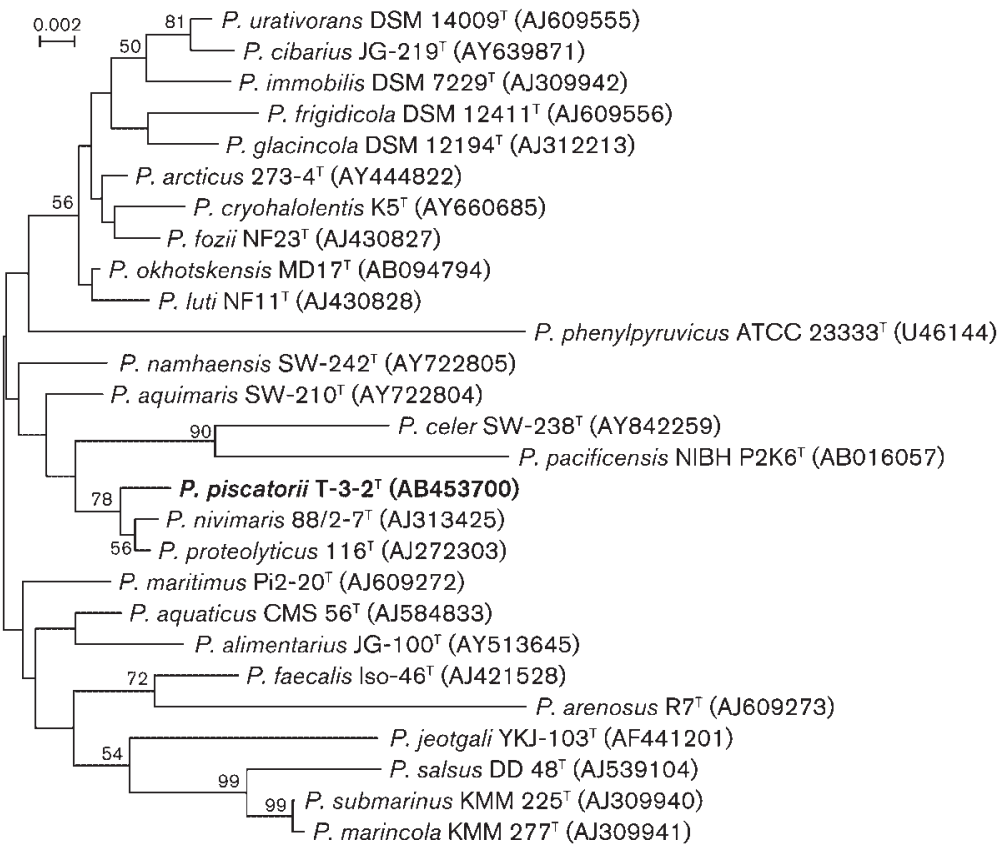

Fig. 1. Neighbour-joining phylogenetic tree derived from 16S rRNA gene sequences of Psychrobacter piscatorii sp. nov. T-3-2 ${ }^{\top}$ and related members of the genus Psychrobacter. Bootstrap values (expressed as percentages of 1000 replicates) $\geqslant 50 \%$ are shown at branch points. Bar, 0.002 expected base substitutions per nucleotide position. 


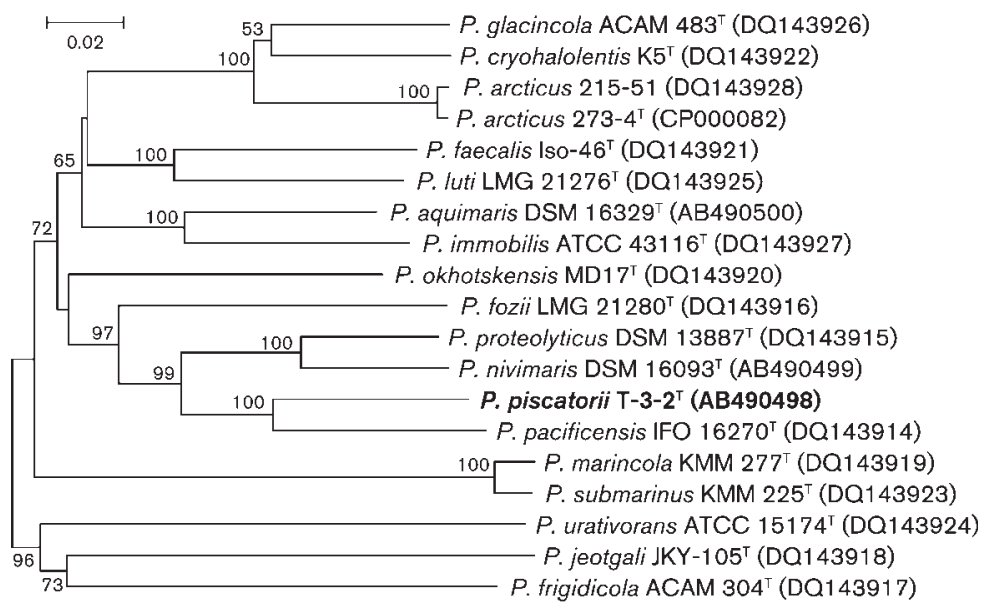

Fig. 2. Neighbour-joining phylogenetic tree derived from gyrB gene sequences of $P$. piscatorii sp. nov. T-3-2 ${ }^{\top}$ and related members of the genus Psychrobacter. Bootstrap values (expressed as percentages of 1000 replicates) $>50 \%$ are shown at branch points. Bar, 0.02 expected base substitutions per nucleotide position.

phylogenetic tree of the strain together with its closely related neighbours was constructed by the neighbourjoining method (Kimura, 1980; Saitou \& Nei, 1987) using the program CLUSTAL W (Thompson et al., 1994) in MEGA4 (Tamura et al., 2007) (Fig. 1). The similarity between sequences was calculated using the GENETYX computer program (Software Development). The strain showed the highest similarity to $P$. nivimaris DSM $16093^{\mathrm{T}}(99.2 \%)$ among strains of reported species. It also showed high sequence similarity to its phylogenetic neighbours $P$. proteolyticus DSM $13887^{\mathrm{T}}(98.5 \%)$ and $P$. aquimaris DSM $16329^{\mathrm{T}}(98.7 \%)$. The gyrB gene was amplified and sequenced as described by Bakermans et al. (2006). Sequences were determined and trees constructed as described above (Fig. 2). The result showed a resolution greater than that based on $16 \mathrm{~S}$ rRNA gene sequence analyses. The strain showed the highest similarity to Psychrobacter pacificensis IFO $16270^{\mathrm{T}}$ (89.8\%) among strains of reported species. It also showed high sequence similarity to $P$. nivimaris DSM $16093^{\mathrm{T}}(86.9 \%)$ and $P$. proteolyticus DSM $13887^{\mathrm{T}}$ (86.6\%).

The level of DNA-DNA relatedness was determined fluorometrically by the method of Ezaki et al. (1989) using photobiotin-labelled DNA probes and black microplates. The hybridization temperature was $38.5{ }^{\circ} \mathrm{C}$. According to the sequence similarities and phylogenetic analysis based on the 16S rRNA gene sequence, strain HT- $3^{\mathrm{T}}$ is most closely related to $P$. nivimaris DSM $16093^{\mathrm{T}}$ among strains assigned to named species. DNA-DNA hybridizations were performed between strain $\mathrm{HT}-3^{\mathrm{T}}$ and P. nivimaris DSM $16093^{\mathrm{T}}$, P. proteolyticus DSM $13887^{\mathrm{T}}$ and P. aquimaris DSM $16329^{\mathrm{T}}$; these experiments indicated that the isolate is distinct from P. nivimaris DSM $16093^{\mathrm{T}}$ ( $64 \%$ relatedness), P. proteolyticus DSM $13887^{\mathrm{T}}(36 \%)$ and P. aquimaris DSM $16329^{\mathrm{T}}(31 \%)$.

Strain $\mathrm{HT}-3^{\mathrm{T}}$ can also be differentiated from other phylogenetic neighbours including $P$. nivimaris on the basis of several phenotypic and chemotaxonomic characteristics (Table 1).

Table 1. Differential phenotypic characteristics of strain T-3$2^{\top}$ and related Psychrobacter species

Strains: $1, P$. piscatorii sp. nov. T- $3-2^{\mathrm{T}} ; 2, P$. nivimaris $88 / 2-7^{\mathrm{T}}$ (unless indicated, data from Heuchert et al., 2004); 3, P. proteolyticus $116^{\mathrm{T}}$ (Denner et al., 2001; Bozal et al., 2003); 4, P. aquimaris SW-210 (Yoon et al., 2005); 5, P. pacificensis (data for six strains) (Maruyama et al., 2000). Acid production from substrates and utilization of substrates were determined in this study under the same experimental conditions. +, Positive; $\mathrm{w}$, weakly positive; $\mathrm{v}-$, variable, type strain negative; -, negative; ND, no data available.

\begin{tabular}{|c|c|c|c|c|c|}
\hline Characteristic & 1 & 2 & 3 & 4 & 5 \\
\hline Anaerobic growth & - & ND & - & + & - \\
\hline Urease & $\mathrm{W}$ & ND & + & - & + \\
\hline Nitrate reduction & $\mathrm{W}$ & ND & - & - & - \\
\hline \multicolumn{6}{|l|}{$\begin{array}{l}\text { Temperature for } \\
\text { growth }\left({ }^{\circ} \mathrm{C}\right)\end{array}$} \\
\hline Maximum & 30 & 35 & $<35$ & 34 & 38 \\
\hline Optimum & $24-26$ & $10-15$ & $19-25$ & $25-30$ & 25 \\
\hline \multicolumn{6}{|l|}{ Acid production from: } \\
\hline D-Glucose & + & + & - & + & + \\
\hline D-Xylose & + & - & - & + & + \\
\hline L-Arabinose & + & - & - & + & + \\
\hline D-Fructose & - & - & - & - & $\mathrm{ND}$ \\
\hline L-Rhamnose & + & - & - & + & ND \\
\hline D-Galactose & + & + & - & + & ND \\
\hline Maltose & - & - & - & - & ND \\
\hline Lactose & - & - & - & - & ND \\
\hline \multicolumn{6}{|l|}{ Utilization of: } \\
\hline Acetate & + & + & - & + & $\mathrm{V}-$ \\
\hline Pyruvate & + & + & + & + & ND \\
\hline Malate & + & - & - & + & + \\
\hline Succinate & + & - & + & + & $\mathrm{ND}$ \\
\hline $\begin{array}{l}\text { DNA G }+ \text { C content } \\
(\mathrm{mol} \%)\end{array}$ & 43.9 & 42 & 43.6 & 43.2 & $43-44$ \\
\hline
\end{tabular}


On the basis of the above results, the isolate was assigned to a novel species, for which the name Psychrobacter piscatorii sp. nov. is proposed.

\section{Description of Psychrobacter piscatorii sp. nov.}

Psychrobacter piscatorii (pis.ca.to'ri.i. L. n. piscatorium a fishing place; L. gen. n. piscatorii of a fishing place, because the type strain was isolated from a fish-processing factory).

Cells are coccobacilli $(0.9-1.1 \times 1.3-1.6 \mu \mathrm{m})$, Gram-negative and without flagella. Colonies are circular, convex and white with entire margins. Positive for catalase and oxidase. Produces acid from L-arabinose, ribose, D-xylose, Dglucose, D-mannose, D-galactose, L-rhamnose and D-fucose but not from fructose, maltose, sucrose, lactose, raffinose, myo-inositol, mannitol, sorbitol or glycerol under aerobic conditions. Growth occurs in medium supplemented with $0-12 \% \mathrm{NaCl}$, but not at $>15 \% \mathrm{NaCl}$. Growth occurs at 0 $30{ }^{\circ} \mathrm{C}$. Positive for production of $\mathrm{H}_{2} \mathrm{~S}$ and Simmons' citrate, but negative in the Voges-Proskauer, methyl red and ONPG tests. Tributyrin and Tweens 20, 40, 60 and 80 are hydrolysed, but casein, gelatin, starch, DNA, alginic acid and aesculin are not. Utilizes L-arabinose, acetate, pyruvate, succinate and malate as sole carbon and energy sources for growth, but not D-fructose, glycerol, maltose or citrate. Whole-cell fatty acids consist predominantly of $\mathrm{C}_{16: 1} \omega 9 c$ and $\mathrm{C}_{18: 1} \omega 9 c$. The major isoprenoid quinone is Q-8. The DNA $\mathrm{G}+\mathrm{C}$ content of the type strain is $43.9 \mathrm{~mol} \%$, as determined by HPLC.

The type strain, T-3-2 $2^{\mathrm{T}}\left(=\mathrm{JCM} 15603^{\mathrm{T}}=\mathrm{NCIMB} 14510^{\mathrm{T}}\right)$, was isolated from a drain of a fish-processing plant.

\section{References}

Bakermans, C., Ayala-del-Río, H. L., Ponder, M. A., Vishnivetskaya, T., Gilichinsky, D., Thomashow, M. F. \& Tiedje, J. M. (2006). Psychrobacter cryohalolentis sp. nov. and Psychrobacter arcticus sp. nov., isolated from Siberian permafrost. Int J Syst Evol Microbiol 56, 1285-1291.

Barrow, G. I. \& Feltham, R. K. A. (editors) (1993). Cowan and Steel's Manual for the Identification of Medical Bacteria, 3rd edn. Cambridge: Cambridge University Press.

Bozal, N., Montes, J., Tudela, E. \& Guinea, J. (2003). Characterization of several Psychrobacter strains isolated from Antarctic environments and description of Psychrobacter luti sp. nov. and Psychrobacter fozii sp. nov. Int J Syst Evol Microbiol 53, 1093-1100.

Denner, E. B. M., Mark, B., Busse, H.-J., Turkiewicz, M. \& Lubits, W. (2001). Psychrobacter proteolyticus sp. nov., a psychrotrophic, halotolerant bacterium isolated from the Antarctic krill Euphausia superba Dana, excreting a cold-adapted metalloprotease. Syst Appl Microbiol 24, 44-53.

Ezaki, T., Hashimoto, Y. \& Yabuuchi, E. (1989). Fluorometric deoxyribonucleic acid-deoxyribonucleic acid hybridization in microdilution wells as an alternative to membrane filter hybridization in which radioisotopes are used to determine genetic relatedness among bacterial strains. Int J Syst Bacteriol 39, 224-229.

Gerday, C. \& Glansdorff, N. (editors) (2007). Physiology and Biochemistry of Extremophiles. Washington, DC: American Society for Microbiology.
Heuchert, A., Glöckner, F. O., Amann, R. \& Fischer, U. (2004). Psychrobacter nivimaris sp. nov., a heterotrophic bacterium attached to organic particles isolated from the South Atlantic (Antarctica). Syst Appl Microbiol 27, 399-406.

Hugh, R. \& Leifson, E. (1953). The taxonomic significance of fermentative versus oxidative metabolism of carbohydrates by various Gram-negative bacteria. J Bacteriol 66, 24-26.

Jamet, A., Sigaud, S., Van de Sype, G., Puppo, A. \& Hérouart, D. (2003). Expression of the bacterial catalase genes during Sinorhizobium meliloti-Medicago sativa symbiosis and their crucial role during the infection process. Mol Plant Microbe Interact 16, 217 225.

Katsuwon, J. \& Anderson, A. J. (1992). Characterization of catalase activities in a root-colonizing isolate of Pseudomonas putida. Can J Microbiol 38, 1026-1032.

Kimura, M. (1980). A simple method for estimating evolutionary rates of base substitutions through comparative studies of nucleotide sequences. J Mol Evol 16, 111-120.

Marmur, J. (1961). A procedure for the isolation of deoxyribonucleic acid from microorganisms. J Mol Biol 3, 208-218.

Maruyama, A., Honda, D., Yamamoto, H., Kitamura, K. \& Higashihara, T. (2000). Phylogenetic analysis of psychrophilic bacteria isolated from the Japan Trench, including a description of the deep-sea species Psychrobacter pacificensis sp. nov. Int J Syst Evol Microbiol 50, 835-846.

Merle, P.-L., Sabourault, C., Richier, S., Allemand, D. \& Furla, P. (2007). Catalase characterization and implication in bleaching of a symbiotic sea anemone. Free Radic Biol Med 42, 236-246.

Rocha, E. R., Selby, T., Coleman, J. P. \& Smith, C. J. (1996). Oxidative stress response in an anaerobe, Bacteroides fragilis: a role for catalase in protection against hydrogen peroxide. J Bacteriol 178, 6895-6903.

Saitou, N. \& Nei, M. (1987). The neighbor-joining method: a new method for reconstructing phylogenetic trees. Mol Biol Evol 4, 406425.

Tamaoka, J. \& Komagata, K. (1984). Determination of DNA base composition by reversed-phase high-performance liquid chromatography. FEMS Microbiol Lett 25, 125-128.

Tamura, K., Dudley, J., Nei, M. \& Kumar, S. (2007). MEGA4: molecular evolutionary genetic analysis (MEGA) software version 4.0. Mol Biol Evol 24, 1596-1599.

Thompson, J. D., Higgins, D. G. \& Gibson, T. J. (1994). CLUSTAL W: improving the sensitivity of progressive multiple sequence alignment through sequence weighting, position-specific gap penalties and weight matrix choice. Nucleic Acids Res 22, 4673-4680.

Visick, K. L. \& Ruby, E. G. (1998). The periplasmic, group III catalase of Vibrio fischeri is required for normal symbiotic competence and is induced both by oxidative stress and by approach to stationary phase. J Bacteriol 180, 2087-2092.

Yoon, J.-H., Lee, C.-H., Yeo, S.-H. \& Oh, T.-K. (2005). Psychrobacter aquimaris sp. nov. and Psychrobacter namhaensis sp. nov., isolated from sea water of the South Sea in Korea. Int J Syst Evol Microbiol 55, 1007-1013.

Yumoto, I., Yamazaki, K., Hishinuma, M., Nodasaka, Y., Suemori, A., Nakajima, K., Inoue, N. \& Kawasaki, K. (2001). Pseudomonas alcaliphila sp. nov., a novel facultatively psychrophilic alkaliphile isolated from seawater. Int J Syst Evol Microbiol 51, 349-355.

Yumoto, I., Hishinuma-Narisawa, M., Hirota, K., Shingyo, T., Takebe, F., Nodasaka, Y., Matsuyama, H. \& Hara, I. (2004). Exiguobacterium oxidotolerans sp. nov., a novel alkaliphile exhibiting high catalase activity. Int J Syst Evol Microbiol 54, 2013-2017. 